\title{
Effects of maternal protein restriction during pregnancy and lactation on milk composition and offspring development
}

\author{
C. J. Bautista ${ }^{1}$, R. J. Bautista ${ }^{1}$, S. Montaño ${ }^{2}$, L. A. Reyes-Castro ${ }^{1}$, O. N. Rodriguez-Peña ${ }^{1,3}$, C. A. Ibáñez ${ }^{1}$, \\ P. W. Nathanielsz ${ }^{4}$ and E. Zambrano ${ }^{1 *}$ \\ ${ }^{1}$ Departamento de Biología de la Reproducción, Instituto Nacional de Ciencias Médicas y Nutrición Salvador Zubirán, Mexico \\ City, Mexico \\ ${ }^{2}$ Departamento de Nutrición Animal, Instituto Nacional de Ciencias Médicas y Nutrición Salvador Zubirán, Mexico City, \\ Mexico \\ ${ }^{3}$ Unidad de Biotecnología y Prototipos (UBIPRO), FES Iztacala, UNAM, Mexico City, Mexico \\ ${ }^{4}$ Department of Animal Science, University of Wyoming, Laramie, WY, USA
}

(Submitted 13 July 2018 - Final revision received 2 April 2019 - Accepted 24 April 2019; First published online 26 July 2019)

\section{Abstract}

Before weaning, breast milk is the physiological form of neonatal nutrition, providing pups with all nutrient requirements. Maternal low-protein diet (LPD) during pregnancy and lactation induces adverse changes in key maternal organs, which have negative effects on pup development. We studied the effects of maternal LPD on liver weight, mammary gland (MG) cell differentiation, milk composition and production and pup development throughout lactation. We fed rats with control (C) or LPD (R) during pregnancy and lactation. At $7 \mathrm{~d}$ early, $14 \mathrm{~d}$ mid and $21 \mathrm{~d}$ late lactation stages, maternal biochemical parameters, body, liver and MG weights were analysed. MG cell differentiation was analysed by haematoxylin and eosin staining; milk nutrient composition and production were studied; pup body, liver and brain weights, hippocampal arachidonic acid (AA) and DHA were quantified. Results showed lower body and liver weights, minor MG cell differentiation and lower serum insulin and TAG in R compared with C. R milk contained less protein and higher AA at early and mid stages compared with C. R pup milk and fat intake were lower at all stages. R protein intake at early and mid stages and DHA intake at mid and late stages were lower compared with C. In R pups, lower body, liver and brain weights were associated with decreased hippocampal AA and DHA. We conclude that maternal LPD impairs liver and MG function and induces significant changes in maternal milk composition, pup milk intake and organ development.

Key words: Maternal undernutrition: Mammary glands: Milk production: Brain: Hippocampus: Neonatal growth

Maternal milk is widely considered the best feeding source for newborns compared with the alternatives ${ }^{(1-3)}$, even in the setting of maternal undernutrition during pregnancy and lactation, which not only affects maternal health but negatively programmes neonatal growth and organ development and maturation $^{(4-8)}$. Reduced maternal nutrition is the most extensively studied programming challenge of offspring phenotypic plasticity $^{(9)}$. Developmental programming is defined as the response to a specific challenge to the mammalian organism during a critical developmental time window that alters the trajectory of development with resulting effects on health that persist throughout life $\mathrm{e}^{(10,11)}$. The implications of maternal undernutrition on milk quality and their consequences on maternal neonatal growth and development, to date, have been poorly studied.
During the early stages of lactation (0-7 days of lactation, $\mathrm{dL}$ ) pups cannot synthesise many key metabolites. These must be provided in the maternal milk ${ }^{(12)}$. Among the best known examples are the long-chain (LC)-PUFA, especially arachidonic acid (AA) and DHA, which are essential for offspring metabolic functions, for example, in liver and brain maturation ${ }^{(13,14)}$. This need for LC-PUFA is particularly marked in the hippocampus, a major centre of behavioural control and cognitive function ${ }^{(15-17)}$. By mid lactation (8-14 dL), maximal milk production is associated with changes in maternal metabolism, hormone synthesis and physiological adaptations ${ }^{(18)}$. During this stage, pup growth increases dramatically and organ maturation accelerates ${ }^{(7)}$. If nutrition is adequate, then the neonate has been prepared for an independent existence by the end of lactation $(21 \mathrm{dL})^{(19-21)}$.

Abbreviations: AA, arachidonic acid; C, control group; dL, days of lactation; HOMA, homeostatic model assessment; LC, long-chain; LPD, low-protein diet; MG, mammary gland; $\mathrm{R}$, restricted group.

* Corresponding author: Elena Zambrano, email zamgon@yahoo.com.mx 
We have shown that maternal low-protein diet (LPD) during pregnancy impairs maternal liver fat composition ${ }^{(22)}$ and mammary gland (MG) development and function at the end of pregnancy ${ }^{(4)}$, accompanied by decreased maternal and pup LCPUFA in both organs. Previous publications have reported nutrient content ${ }^{(23)}$, milk intake ${ }^{(24,25)}$ or pup body weight gain ${ }^{(19,26)}$ using the LPD model in rats. In the present study we evaluated the effects of maternal LPD on maternal liver metabolism, MG development and milk nutrient composition and production, and their consequences on pup milk nutrient intake and development at different lactation stages throughout lactation in rats. We hypothesised that maternal LPD during pregnancy and lactation results in maternal metabolic adaptations that lead to early programming of dysfuction in offspring organ development.

\section{Methods \\ Care and maintenance of animals}

All procedures were approved by the Animal Experimentation Ethics Committee of the Instituto Nacional de Ciencias Médicas y Nutrición Salvador Zubirán (INCMNSZ, BRE-105). Female albino Wistar rats approximately $120 \mathrm{~d}$ of age and weighing 200-240 g were assigned either to a control group (C: $20 \%$ protein; $n$ 21; seven animals per each stage of lactation) in which mothers ate control diet during pregnancy and lactation; or a restricted group (R: $10 \%$ protein; $n$ 18; six animals at each of the three stages studied) in which mothers ate a protein-restricted diet during pregnancy and lactation ${ }^{(7)}$. Water and food were provided ad libitum to all animals. Food was provided in the form of large flat biscuits retained behind a grill through which the food could be nibbled. Complete details of the maternal diet (Table 1), breeding and management have been published ${ }^{(7)}$. The day of delivery was considered as postnatal day 0 of life. Maternal and pup weights (g) were recorded throughout lactation: at $7 \mathrm{dL}$ (early lactation), $14 \mathrm{dL}$ (mid lactation) and $21 \mathrm{dL}$ (late lactation) ${ }^{(7)}$. To ensure homogeneity of study subjects, litters $>14$ pups or $<12$ pups were not included in the study. Litters of 12-14 pups were adjusted to 12 pups for each mother while maintaining a sex ratio as close as possible to 1:1.

\section{Maternal parameters}

Blood collection. C ( $n$ 7) and $\mathrm{R}(n 6)$ rats were anaesthesised with isoflourane, followed by rapid decapitation, by personnel

Table 1. Maternal diet composition during pregnancy and lactation.

\begin{tabular}{lcc}
\hline & Control diet (\%) & Restricted diet (\%) \\
\hline Casein & 20 & 10 \\
Cystine & 0.3 & 0.15 \\
Choline & 0.165 & 0.165 \\
Vitamin mix & 1 & 1 \\
Mineral mix & 5 & 5 \\
Cellulose & 5 & 5 \\
Maize oil & 5 & 5 \\
Carbohydrates & & \\
$\quad$ Maize starch & 31.76 & 37.34 \\
$\quad$ Dextrose & 31.76 & 37.34 \\
kcal/g of diet & 4 & 4 \\
kJ/g of diet & 16.7 & 16.7 \\
\hline
\end{tabular}

experienced in using a rodent guillotine (Thomas Scientific) on 7, 14 and $21 \mathrm{dL}$. Trunk blood was collected in polyethylene tubes, allowed to clot at $4^{\circ} \mathrm{C}$ for $1 \mathrm{~h}$, centrifuged at $1500 \mathrm{~g}$ for $15 \mathrm{~min}$ at $4^{\circ} \mathrm{C}$ and serum stored at $-20^{\circ} \mathrm{C}$ until assayed. Serum glucose $(\mathrm{mg} / \mathrm{dl})$ and TAG $(\mathrm{mg} / \mathrm{dl})$ concentrations were determined enzymatically using a Synchron $\mathrm{CX}^{\circledR}$ autoanalyser (Beckman Coulter Co.). Serum insulin concentration $(\mathrm{ng} / \mathrm{ml})$ was determined by RIA using commercial rat kits from Linco Research ${ }^{\circledR}$. Homeostatic model assessment (HOMA) was calculated from baseline values using the formula: HOMA = glucose $(\mathrm{mmol} / \mathrm{l}) \times$ insulin $(\mu \mathrm{U} / \mathrm{ml}) / 22 \cdot 5^{(27)}$. Each serum sample was determined in duplicate. The intra- and interassay coefficients of variation were $<4$ and $<6 \%$, respectively ${ }^{(7)}$.

Liver and mammary gland analyses. Maternal liver ${ }^{(22)}$ and complete MG chain were excised and weighed ${ }^{(4)}$. MG beneath the 6th right nipple (counted from the cephalad end) was longitudinally sectioned into two equal parts; one was immediately frozen at $-20^{\circ} \mathrm{C}$ and the other immediately immersion-fixed in $4 \%$ paraformaldehyde in neutral PBS. After $24 \mathrm{~h}$ of fixation, tissue sections were dehydrated with ethanol at increasing concentrations from 75 to $95 \%$ and embedded in paraffin. Sections $(5 \mu \mathrm{m})$ were stained with haematoxylin and eosin.

Mammary gland cell differentiation morphometric analysis. Morphometric analysis was performed on 10 pictures from 3 to 5 sections from each MG, and at least 150 lobules were quantified at $10 \times$ magnification. Adipose and parenchymal tissue (\%; acinar and ductal epithelium) areas were determined. Fifty acini per animal were measured at a higher magnification (100x), and results expressed as cytoplasm area $\left(\mu \mathrm{m}^{2}\right)$ and nuclei size $\left(\mu \mathrm{m}^{2}\right)$ for cells in each acinus (around 7-15 cells per acinus) with AxioVision ${ }^{\circledR}$ software. All histological measurements were performed by two independent observers without knowledge of the source of the tissues, and results were averaged for each animal $^{(14)}$.

\section{Milk parameters}

Nutrient content. Milk samples were collected on 7, 14 and $21 \mathrm{dL}$. Pups were removed from their mothers for $4 \mathrm{~h}$ after which mothers received $0.8 \mathrm{U}$ oxytocin (intraperitoneally), and milk was expressed $15 \mathrm{~min}$ later. Milk samples were vortexed and divided into three aliquots of $1.5 \mathrm{ml}$ and immediately frozen at $-20^{\circ} \mathrm{C}$ until analysed. For analysis, milk samples were thawed at $37^{\circ} \mathrm{C}$ and shaken vigorously before removing assay aliquots to ensure sample uniformity as previously reported ${ }^{(7)}$. Water content (\% of total milk) was analysed by gravimetric analysis ${ }^{(28)}$. Protein content (\%) was measured by Bradford assay (Biorad ${ }^{\circledR}$ ). Total fat content (\%) was measured by the Folch method ${ }^{(22)}$. AA and DHA content from milk fat were measured by gas chromatography ${ }^{(4)}$.

Production and pups' milk component intake. Milk production was estimated as described by Russell and our published data $^{(7,29,30)}$. At 07.00 hours on 6, 13 and $20 \mathrm{dL}$, pups were removed from their mothers for $4 \mathrm{~h}$ during which time mothers had free access to water and ate ad libitum (to produce milk), whereas the pups did not eat. Mothers were weighed at the beginning and end of the 4 -h period. Pups were weighed individually immediately before they were returned to the mothers and again $1 \mathrm{~h}$ later. Pups' milk component intakes (water, 
protein, fat, AA and DHA) were estimated by milk intake $(\mathrm{g} / \mathrm{h}) \times$ milk component (\%)/ 100.

\section{Pup parameters}

Body, liver and brain weight. Pup body weight ( $n 12$ pups per litter per age for both $\mathrm{C}$ and $\mathrm{R}$ ) was registered and liver and brain excised, cleaned and weighed (g) at 7 (early), 14 (middle) and 21 (late) dL. The hippocampus was dissected and immediately frozen and stored at $-70^{\circ} \mathrm{C}$ until use.

Fatty acid analysis. Maternal milk and pup hippocampal lipids were extracted by a modified Folch technique ${ }^{(22)}$. Briefly, samples were homogenised with $2 \mathrm{ml}$ of $0.9 \% \mathrm{NaCl}$ and $5 \mathrm{ml}$ chloroform-methanol (2:1) as previously described ${ }^{(22)}$. Fatty acid extraction was performed by the addition of chloroform $(3 \times 2 \mathrm{ml})$. The organic phase was pooled and 120-150 $\mu$ methanol was added until the organic phase turned transparent, then $1 \mathrm{~g}$ $\mathrm{Na}_{2} \mathrm{SO}_{4}$ was added and vortexed to provide the residue for analysis. The organic phase was evaporated under a stream of $\mathrm{N}_{2}$.

Preparation of fatty acid methyl esters. Samples of fatty acid methyl esters (FAME) were prepared as previously described ${ }^{(22)}$. Briefly, $2 \mathrm{ml}$ methanol, $100 \mu \mathrm{l}$ toluene and $40 \mu \mathrm{l}$ of $2 \%$ methanolic sulfuric acid were added to the above residue and heated at $90^{\circ} \mathrm{C}$ for $2 \mathrm{~h}$. Tubes were then placed on ice, and $1 \mathrm{ml}$ of $5 \% \mathrm{NaCl}$ was added. FAME were extracted with hexane $(3 \times 2 \mathrm{ml})$, and the mixture was centrifuged at $1500 \boldsymbol{g}$ for $1 \mathrm{~min}$. The organic phase was pooled and evaporated under a stream of $\mathrm{N}_{2}$. Hexane $(200 \mu \mathrm{l})$ was added to the residue, which was then centrifuged at $1500 \boldsymbol{g}$ for 5 min. The clear solution was injected in an Agilent ${ }^{\circledR}$ model 6850 gas chromatography system equipped with a flame ionisation detector. Automatic split injection was carried out using an Agilent ${ }^{\circledR} 6850$ auto-sampler. We used an HP-INNO ${ }^{\circledR}$ wax capillary column $(30 \mathrm{~m}, 0.25 \mathrm{~mm}, 0.25 \mathrm{~m}$; J \& W Scientific). Heptadecanoic acid $(125 \mu \mathrm{g})$ was added to $100 \mathrm{mg}$ of the sample as internal standard. A 1- $\mu$ l sample was injected in split mode (50:1) at $250^{\circ} \mathrm{C}$. The carrier gas was He with a constant linear velocity of $24 \mathrm{~cm} / \mathrm{s}$, and the interface temperature was maintained at $280^{\circ} \mathrm{C}$. The oven temperature was raised from 50 to $230^{\circ} \mathrm{C}$. The identification of FAME was based upon retention times obtained for methyl ester standards from Poly Science ${ }^{\circledR}$, and each one was expressed as a percentage of total fatty acids in the sample ${ }^{(22)}$.

\section{Statistical analysis}

To assess the differences within lactation periods in the same experimental group ( $\mathrm{C}$ or $\mathrm{R}$ ) we performed a one-way multiple ANOVA followed by a Tukey test. To compare $\mathrm{C}$ and $\mathrm{R}$ groups, we performed unpaired Student's $t$ tests at the same lactation period. Preliminary analysis revealed no sex-dependent statistical significance by lactational stage, so pup data from the same litter were averaged for analysis. Data are presented as means with their standard errors. Significance was set at $P \leq 0.05$.

\section{Results \\ Maternal parameters}

Body weight. Body weight of $\mathrm{C}$ mothers increased at $14 \mathrm{dL}$ compared with $7 \mathrm{dL}$ and then remained stable. Body weight of $\mathrm{R}$ mothers decreased during lactation. R mothers weighed lower than $\mathrm{C}$ at 14 and $21 \mathrm{dL}$ (Fig. 1(a), $P<0.05$ ).

Glucose, insulin and homeostatic model assessment. Glucose serum levels were constant throughout lactation in C. However, R glucose increased at $21 \mathrm{dL}$ compared with 7 and $14 \mathrm{dL}$. Glucose serum levels were higher in R compared with $\mathrm{C}$ at $21 \mathrm{dL}$ (Fig. 1(b), $P<0.05$ ). Insulin serum levels were lower at $21 \mathrm{dL}$ compared with 14 and $7 \mathrm{dL}$ in C. In the $\mathrm{R}$ group, insulin serum levels decreased during lactation. $\mathrm{R}$ serum levels were lower than in $\mathrm{C}$ at all stages (Fig. 1(c), $P<0 \cdot 05$ ). HOMA was constant throughout lactation in $\mathrm{C}$ and was lower at $21 \mathrm{dL}$ compared with $7 \mathrm{dL}$ in $\mathrm{R}$. However, R HOMA was lower compared with $\mathrm{C}$ at all stages (Fig. 1(d), $P<0.05)$.

TAG. TAG remained constant throughout lactation in C. However, in R, TAG was similar at 7 and $14 \mathrm{dL}$ and increased between 14 and $21 \mathrm{dL}$. TAG was lower throughout lactation in R compared with C (Fig. 1(e), $P<0.05$ ).

Liver weight. Liver weight in $\mathrm{C}$ was higher at $14 \mathrm{dL}$ compared with 7 and $21 \mathrm{dL}$. In R, liver weight increased at $14 \mathrm{dL}$ compared with $7 \mathrm{dL}$ and remained constant until $21 \mathrm{dL}$ (Fig. 1(f), $P<0.05$ ). Lower liver weights were found throughout lactation in R compared with C. Liver weight relative to body weight remained constant throughout lactation in both $\mathrm{C}$ and $\mathrm{R}$ but was lower in $\mathrm{R}$ compared with C (Fig. 1(g), $P<0.05$ ).

Mammary gland weight. In $\mathrm{C}, \mathrm{MG}$ weight was higher at $14 \mathrm{dL}$ compared with 7 and $21 \mathrm{dL}$. In R, MG weight was similar at 7 and $14 \mathrm{dL}$; at $21 \mathrm{dL}, \mathrm{MG}$ weight was lower than at $14 \mathrm{dL}$. Lower MG weights were found in R throughout lactation compared with C (Fig. 1(h), $P<0.05$ ). MG weight relative to body weight was lower in both $\mathrm{C}$ and $\mathrm{R}$ at $21 \mathrm{dL}$ compared with earlier time points. Lower values of $\mathrm{MG}$ weights relative to body weights were found throughout lactation in R compared with C (Fig. 1(i), $P<0.05$ ).

\section{Mammary gland morphometric analysis}

Parenchymal tissue. In $\mathrm{C}$, the percentage of parenchymal tissue was similar at 7 and $14 \mathrm{dL}$ but higher than $21 \mathrm{dL}$. In contrast, R percentage of parenchymal tissue increased during lactation. Lower percentage of parenchymal tissue was present in $\mathrm{R}$ than $\mathrm{C}$ at 7 and $14 \mathrm{dL}$. However, at $21 \mathrm{dL}, \mathrm{R}$ contained a higher percentage of parenchymal tissue compared with C (Fig. 2(a) and (c), $P<0 \cdot 05)$.

Adipose tissue. The percentage of adipose tissue was similar in 7 and $14 \mathrm{dL}$ and increased between 14 and $21 \mathrm{dL}$ in C. In R, the percentage of adipose tissue decreased during lactation. In $\mathrm{R}$, the percentage of adipose tissue was higher at 7 and $14 \mathrm{dL}$ and lower at $21 \mathrm{dL}$ compared with C (Fig. 2(b) and (c), $P<0.05)$.

Cell cytoplasm area. In C, cell cytoplasm area was similar at 7 and $14 \mathrm{dL}$ and higher than $21 \mathrm{dL}$. In R, cytoplasm area was higher at $21 \mathrm{dL}$ compared with $14 \mathrm{dL}$. But it was lower at 7 and $14 \mathrm{dL}$ compared with C (Fig. 3(a) and (c), $P<0.05$ ).

Nuclear size. Nuclear size decreased at $21 \mathrm{dL}$ compared with $14 \mathrm{dL}$ in $\mathrm{C}$, but remained constant throughout lactation in $\mathrm{R}$. Lower values were found in 7 and $14 \mathrm{dL}$ in $\mathrm{R}$ compared with C (Fig. 3(b) and (c), $P<0.05$ ). 


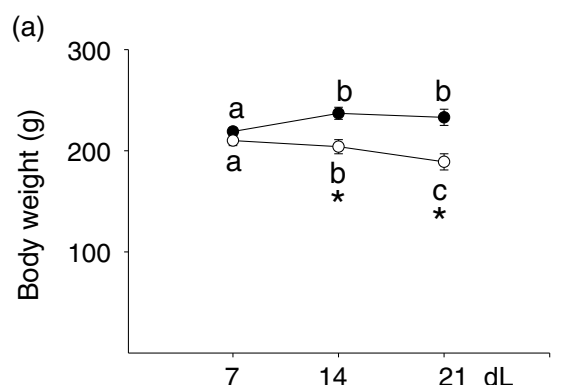

(d)

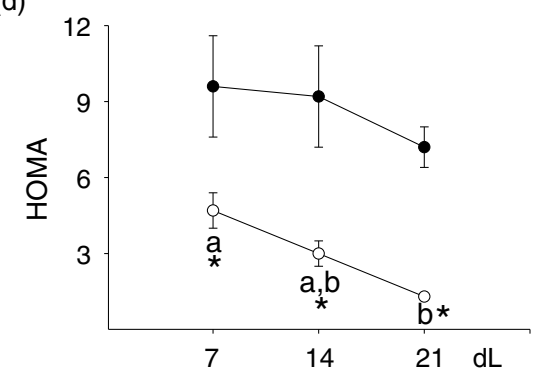

(g)

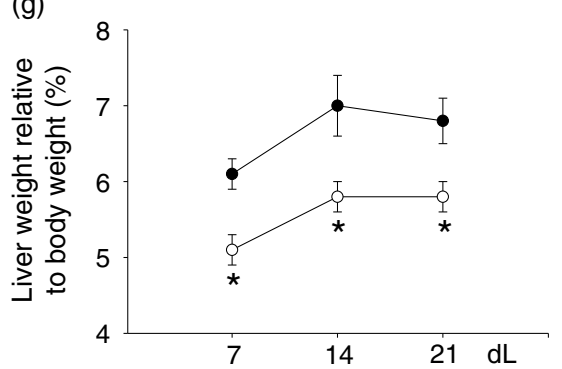

(b)

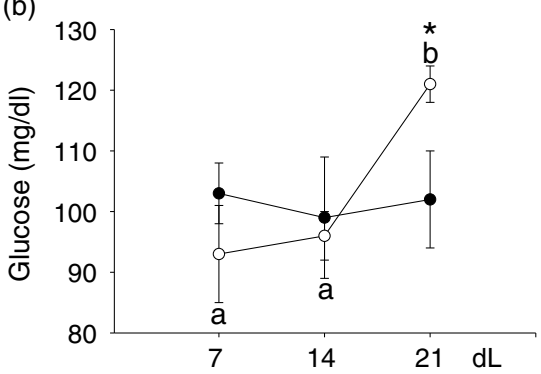

(e)

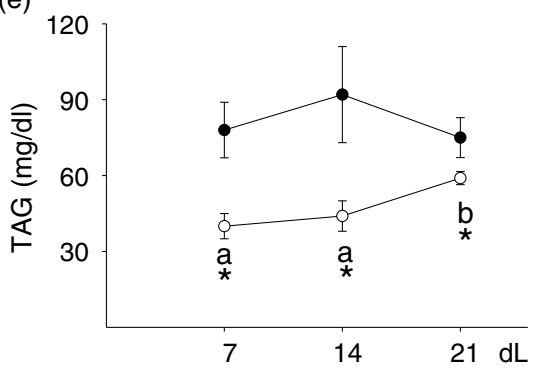

(h)

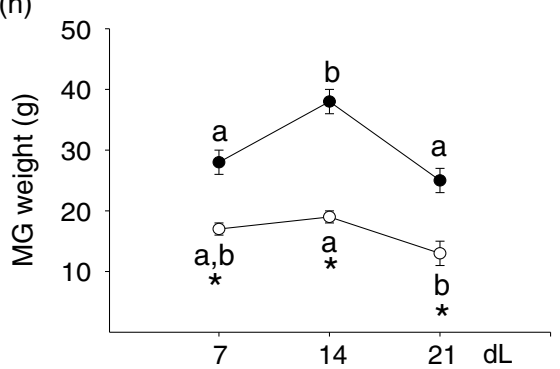

(c)

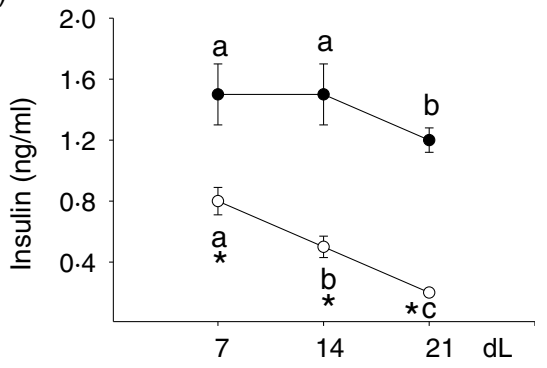

(f)

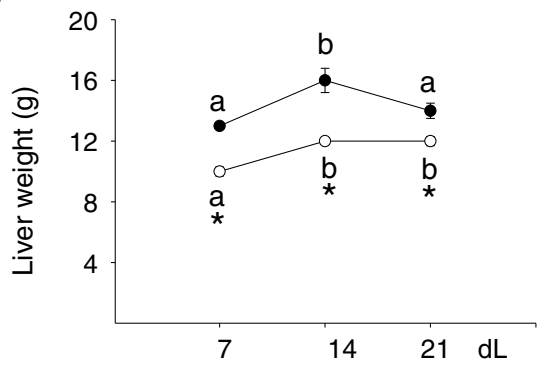

(i)

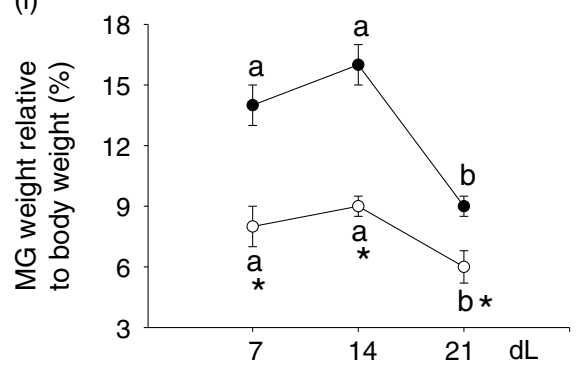

Fig. 1. Maternal parameters. (a) Body weight (g), (b) glucose (mg/dl), (c) insulin (ng/ml), (d) homeostatic model assessment (HOMA), (e) TAG (mg/dl), (f) liver weight (g), (g) liver weight relative to body weight (\%), (h) mammary gland (MG) weight (g), (i) MG weight relative to body weight (\%) at 7 (early stage), 14 (middle stage) and 21 (late stage) days of lactation (dL). Rats were fed control (C: $-20 \%$ protein; $n 7$ per each stage) or restricted (R: $-10 \%$ protein; $n 6$ per each stage) diet during pregnancy and lactation. Values are means, with their standard errors represented by vertical bars. ${ }^{*} P<0.05 \mathrm{v}$. C. Data not sharing a letter are different between ages in the same group $(P<0.05)$. $\bullet$, C group; $\odot, R$ group. To convert glucose in $\mathrm{mg} / \mathrm{dl}$ to $\mathrm{mmol} / \mathrm{l}$, multiply by 0.0555 . To convert TAG in $\mathrm{mg} / \mathrm{dl}$ to $\mathrm{mmol} / \mathrm{l}$, multiply by 0.0113 .

\section{Milk parameters}

Water. No difference in the percentage of water content was observed at any stage of lactation within or between groups (Fig. 4(a), $P<0.05$ ).

Protein. Milk protein content in $\mathrm{C}$ was higher at $14 \mathrm{dL}$ compared with 7 and $21 \mathrm{dL}$, and higher at 21 than $7 \mathrm{dL}$. In R, the protein content was higher at $21 \mathrm{dL}$ compared with other stages. Protein content was lower at 7 and $14 \mathrm{dL}$ in $\mathrm{R}$ compared with C (Fig. 4(b), $P<0.05$ ).

Total fat. Total fat content was lower at $14 \mathrm{dL}$ in comparsion with 7 and $21 \mathrm{dL}$, and lower at $21 \mathrm{dL}$ compared with $7 \mathrm{dL}$ in both $\mathrm{C}$ and $\mathrm{R}$. No differences were found between $\mathrm{C}$ and $\mathrm{R}$ throughout lactation (Fig. 4(c), $P<0.05$ ).

Arachidonic acid. AA increased at $21 \mathrm{dL}$ in C compared with 7 and $14 \mathrm{dL}$, while AA in $\mathrm{R}$ was higher at $21 \mathrm{dL}$ compared with $14 \mathrm{dL}$. Higher AA content was observed at 7 and $14 \mathrm{dL}$ in $\mathrm{R}$ compared with C (Fig. 4(d), $P<0.05$ ).

$D H A$. DHA decreased at $21 \mathrm{dL}$ compared with 14 and $7 \mathrm{dL}$ in both $\mathrm{C}$ and $\mathrm{R}$. No differences were found between $\mathrm{C}$ and $\mathrm{R}$ throughout lactation (Fig. 4(e), $P<0.05$ ).

\section{Milk production and pup milk intake}

Total intake. Total pup milk intake increased between 7 and $14 \mathrm{dL}$ and remained constant until $21 \mathrm{dL}$ in both $\mathrm{C}$ and $\mathrm{R}$. Lower total milk intake throughout lactation was found in R compared with C (Fig. 5(a), $P<0 \cdot 05$ ).

Protein intake. Pup protein intake increased between 7 and $14 \mathrm{dL}$ and remained constant until $21 \mathrm{dL}$ in $\mathrm{C}$. In R, protein intake was higher at $21 \mathrm{dL}$ compared with $7 \mathrm{dL}$. Lower protein intake was found at 7 and $14 \mathrm{dL}$ in R compared with C (Fig. 5(b), $P<0.05)$.

Total fat intake. Pup total fat intake increased at $21 \mathrm{dL}$ compared with $7 \mathrm{dL}$ in both $\mathrm{C}$ and R. Fat intake was lower throughout lactation in R compared with C (Fig. 5(c), $P<0.05$ ).

Arachidonic acid intake. Pup AA intake increased by $21 \mathrm{dL}$ in C compared with 7 and $14 \mathrm{dL}$ and in R compared with $7 \mathrm{dL}$. No differences were found between the groups (Fig. 5(d), $P<0 \cdot 05)$.

DHA intake. Pup DHA intake remained constant throughout lactation in both $\mathrm{C}$ and R (Fig. 5(e)). Lower DHA intake was found at 14 and $21 \mathrm{dL}$ in R compared with C (Fig. 5(e), $P<0.05$ ). 
(a) Parenchymal tissue (\%)

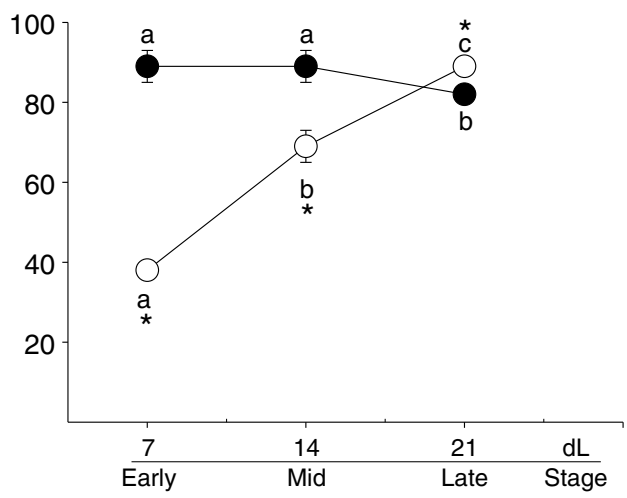

(b) Adipose tissue (\%)

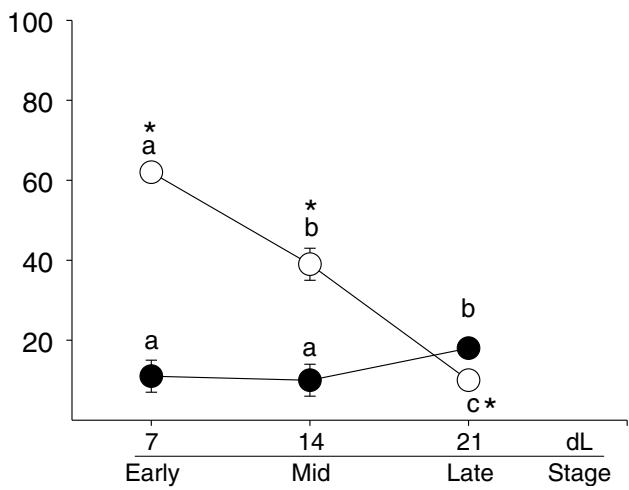

(c)

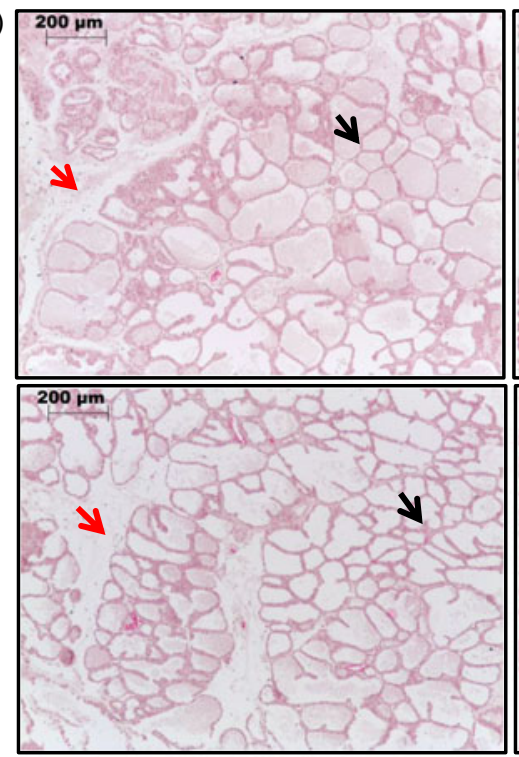

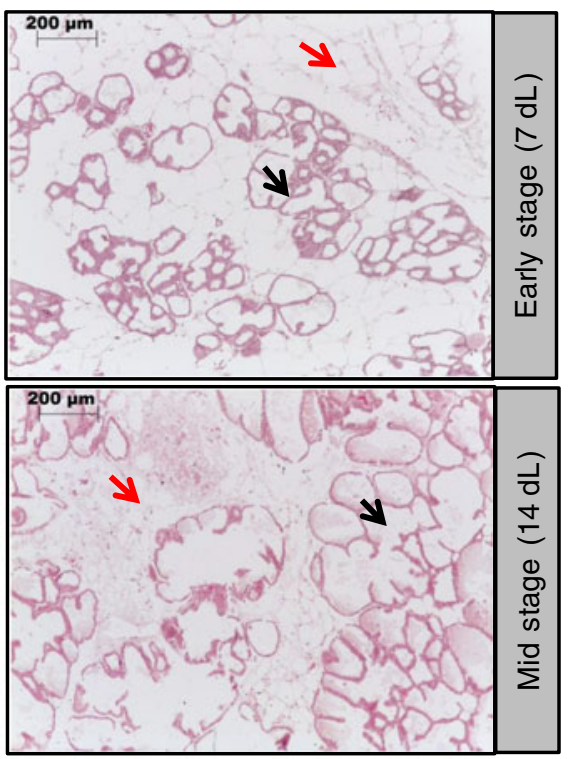
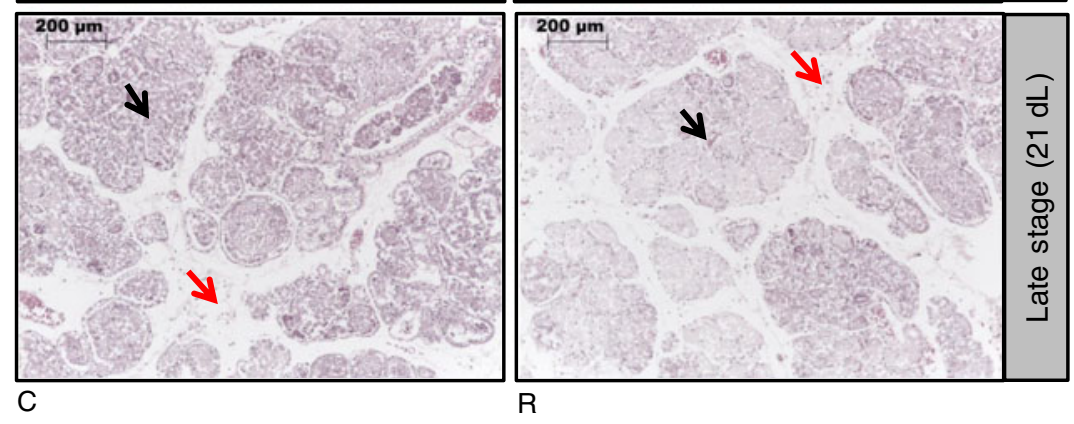

Fig. 2. Mammary gland. (a) Parenchymal tissue (\%), (b) adipose tissue (\%), (c) microphotography with haematoxylin and eosin; 40x. Black arrows point to parenchymal and red adipose tissues, respectively, at 7 (early stage), 14 (middle stage) and 21 (late stage) days of lactation (dL). Rats were fed control (C: $-20 \%$ protein; $n 7$ per each stage) or restricted (R: $-10 \%$ protein; $n 6$ per each stage) diet during pregnancy and lactation. Values are means, with their standard errors represented by vertical bars. ${ }^{*} P<0.05$ v. C. Data not sharing a letter are different between ages in the same group $(P<0.05)$. $\bullet, C$ group; $\circ, \mathrm{R}$ group.

\section{Pup parameters}

Body weight. Pup body weight increased throughout the lactation period in C. However, in R, pup body weight increased at $14 \mathrm{dL}$ and remained constant thereafter. Body weight was lower in R compared with $\mathrm{C}$ at 14 and $21 \mathrm{dL}$ (Fig. 6(a), $P<0.05$ ).

Liver weight. Pup liver weight increased throughout lactation in C. However, in R, pup liver weight increased by $14 \mathrm{dL}$ and remained constant through $21 \mathrm{dL}$. Liver weight was lower throughout lactation in R compared with C (Fig. 6(b), $P<0.05$ ).

Brain weight. Pup brain weight increased throughout lactation in both $\mathrm{C}$ and $\mathrm{R}$. Brain weight was lower at 14 and $21 \mathrm{dL}$ in R compared with C (Fig. 6(c), $P<0.05$ ).

Arachidonic acid in pup hippocampus. Pup hippocampal AA content decreased by $21 \mathrm{dL}$ compared with $7 \mathrm{dL}$ in $\mathrm{C}$ (AA \%: $7 \mathrm{dL}=11 \cdot 2 \pm 0 \cdot 3^{\mathrm{a}} ; 14 \mathrm{dL}=10 \cdot 2 \pm 0 \cdot 2^{\mathrm{ab}} ; 21 \mathrm{dL}=8 \cdot 4 \pm$ $\left.0 \cdot 01^{\mathrm{b}}\right)$. Hippocampal AA levels in $\mathrm{R}$ were constant throughout lactation (AA \%: $7 \mathrm{dL}=6.5 \pm 0.02^{*} ; 14 \mathrm{dL}=5.6 \pm 0.01 * ; 21$ $\mathrm{dL}=5 \cdot 8 \pm 0.01^{*}$ ) and lower than in $\mathrm{C}$ at all stages (Fig. $6(\mathrm{~d})$, $P<0.05)$.

DHA in the pup hippocampus. Pup hippocampal DHA content in $\mathrm{C}$ decreased by $14 \mathrm{dL}$ compared with $7 \mathrm{dL}$ and remained constant until $21 \mathrm{dL}$ (DHA \%: $7 \mathrm{dL}=7 \cdot 2 \pm 0.02^{\mathrm{a}}$; $\left.14 \mathrm{dL}=5 \cdot 5 \pm 0 \cdot 01^{\mathrm{b}} ; 21 \mathrm{dL}=6 \cdot 0 \pm 0 \cdot 02^{\mathrm{b}}\right)$. In R, pup hippocampal DHA decreased throughout lactation (DHA \%: $7 \mathrm{dL}=5.8 \pm$ $\left.0 \cdot 02^{\mathrm{a} *} ; 14 \mathrm{dL}=4 \cdot 1 \pm 0 \cdot 08^{\mathrm{b} *} ; 21 \mathrm{dL}=3 \cdot 2 \pm 0 \cdot 01^{\mathrm{c} *}\right)$. In $\mathrm{R}$, hippocampal DHA was lower than in $\mathrm{C}$ at all stages of lactation (Fig. 6(e), $P<0.05$ ).

\section{Discussion}

Under optimal conditions, breastfeeding provides all the necessary nutrients for neonatal growth and maturation ${ }^{(31,32)}$. Delay in offspring growth velocity during the lactation period may predispose the offspring to metabolic syndrome during adulthood, suggesting that milk composition and intake are important mediators of offspring metabolic programming ${ }^{(24)}$. We studied the effects of maternal LPD on milk quality and production. Previous studies in rats have documented that maternal LPD negatively impacted maternal milk nutrient content ${ }^{(23,24,33)}$, pup milk intake ${ }^{(24,25)}$ and pup body weight ${ }^{(19,26)}$, with negative effects in offspring development ${ }^{(34)}$.

The present study is the first to attempt to analyse the effects of LPD on the delivery of milk nutrients to offspring during 
(a) Cytoplasm $\left(\mu \mathrm{m}^{2}\right)$

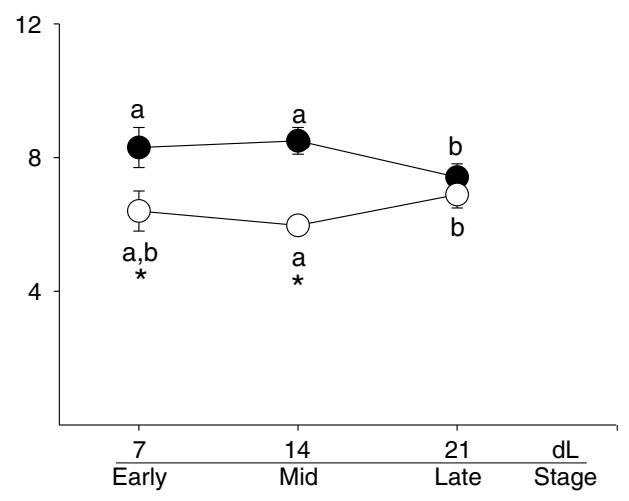

(b) Nuclei size $\left(\mu \mathrm{m}^{2}\right)$

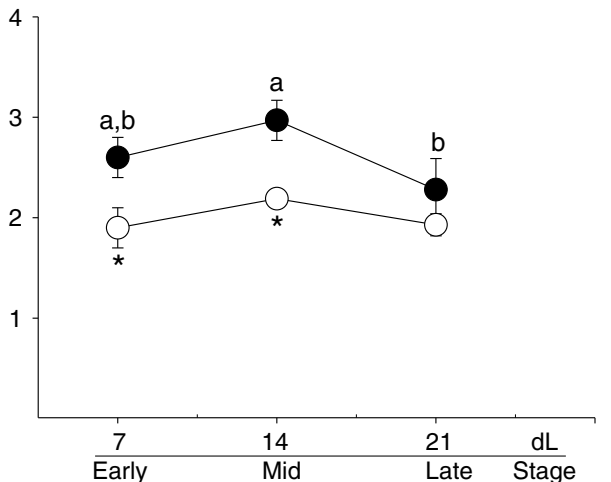

(c)
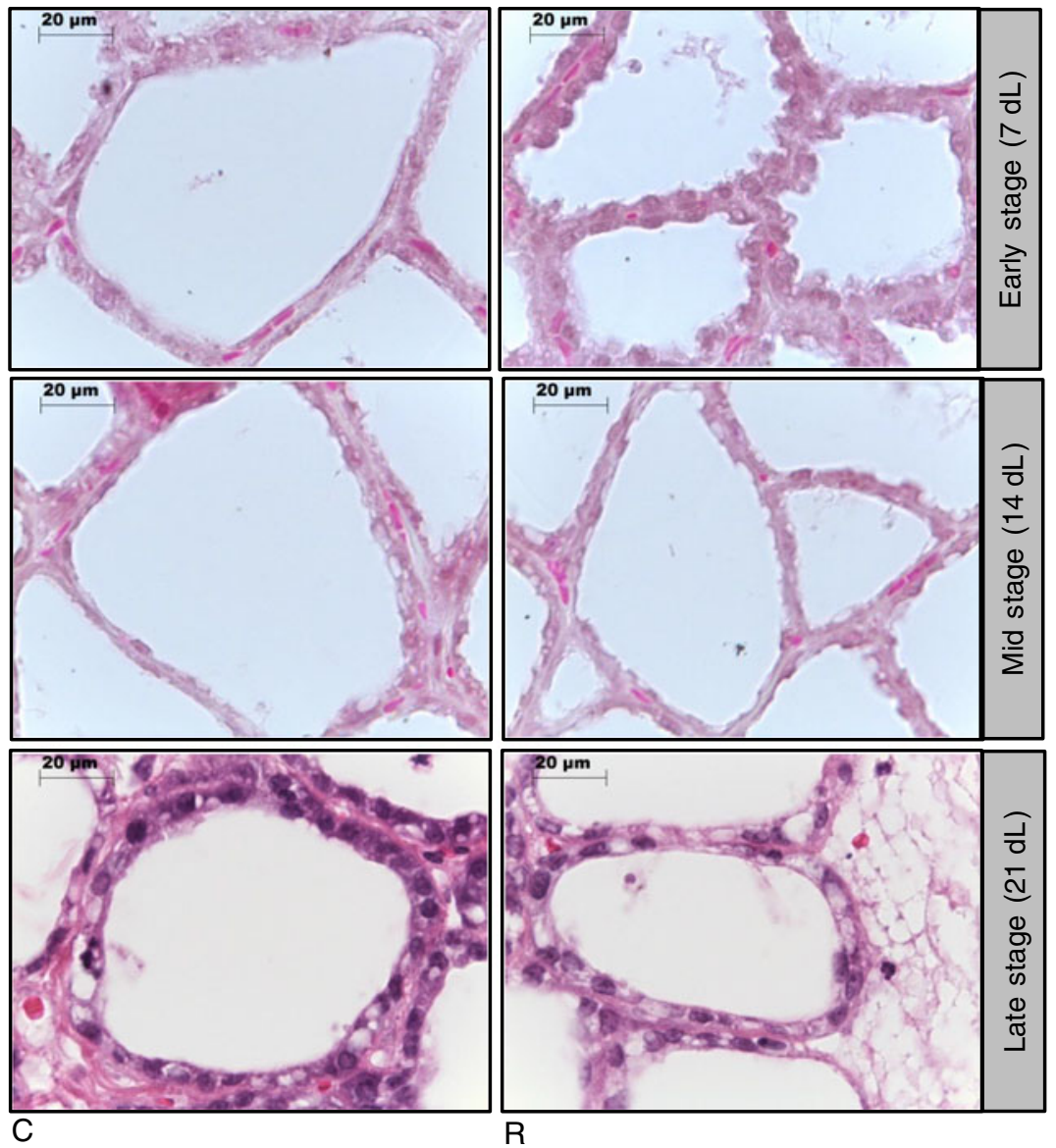

Fig. 3. Mammary gland. (a) Cytoplasm area $\left(\mu \mathrm{m}^{2}\right)$, (b) nuclei size $\left(\mu \mathrm{m}^{2}\right)$, and (c) microphotography with haematoxylin and eosin; $100 \times$ at 7 (early stage), 14 (middle stage) and 21 (late stage) days of lactation (dL). Rats were fed control (C: $-20 \%$ protein; $n 7$ per each stage) or restricted (R: $-10 \%$ protein; $n 6$ per each stage) diet during pregnancy and lactation. Values are means, with their standard errors represented by vertical bars. ${ }^{*} P<0.05 \mathrm{v}$. C. Data not sharing a letter are different between ages in the same group $(P<0.05)$. $\bullet, C$ group; $\odot$, R group.

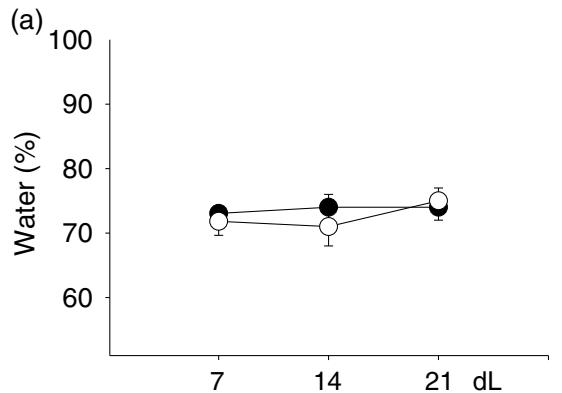

(d) (b)

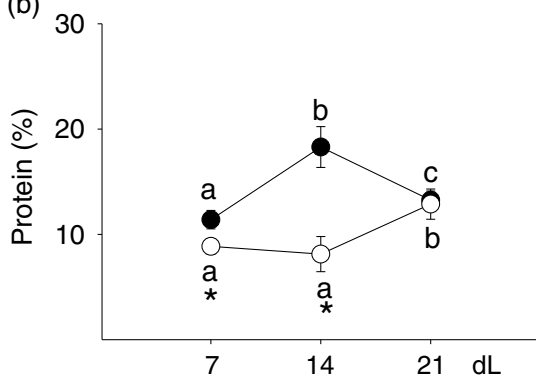

(c)

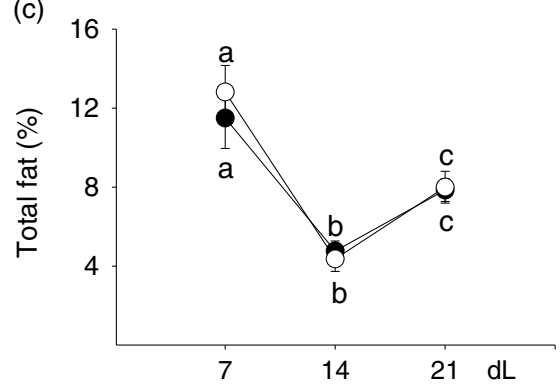

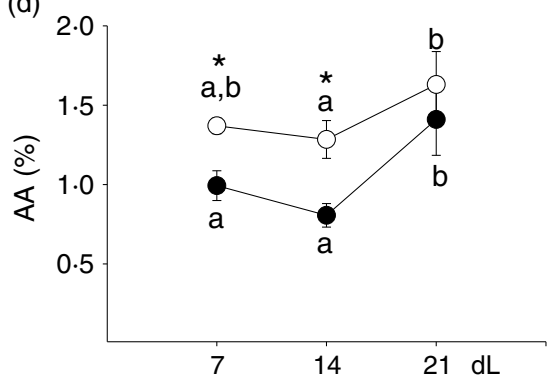

(e)

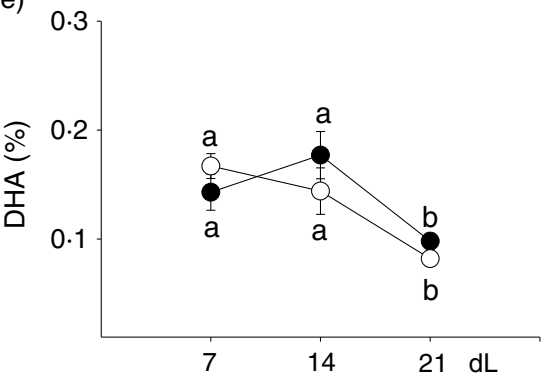

Fig. 4. Milk parameters. (a) Water (\%), (b) protein (\%), (c) total fat (\%), (d) arachidonic acid (AA) (\%), and (e) DHA (\%) at 7 (early stage), 14 (middle stage) and 21 (late stage) days of lactation (dL). Rats were fed control (C: $-20 \%$ protein; $n 7$ per each stage) or restricted (R: $-10 \%$ protein; $n 6$ per each stage) diet during pregnancy and lactation. Values are means, with their standard errors represented by vertical bars. ${ }^{*} P<0.05 \mathrm{v}$. C. Data not sharing a letter are different between ages in the same group $(P<0.05)$. $\bullet$ C group; $\circ$, R group. 
(a)

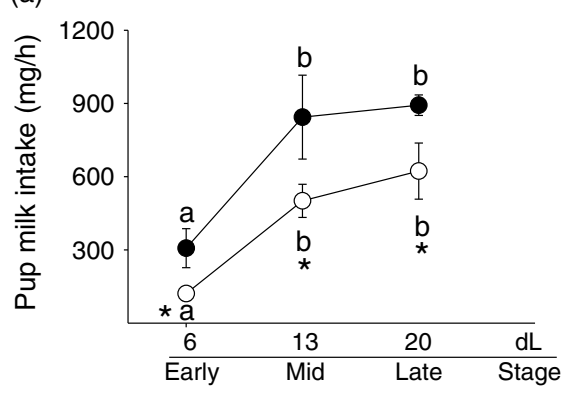

(d) (b)

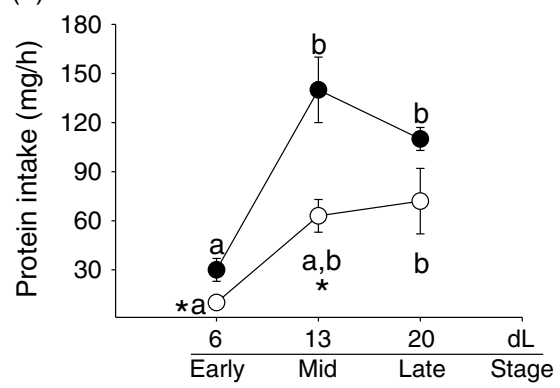

(c)

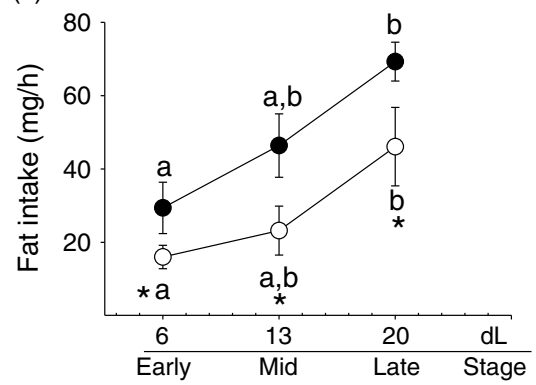

(e)

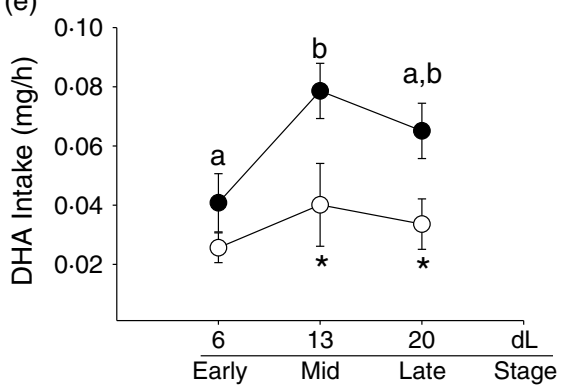

Fig. 5. Pup parameters. (a) Milk intake (g/h), (b) protein intake $(\mathrm{g} / \mathrm{h}),(\mathrm{c})$ total fat intake $(\mathrm{mg} / \mathrm{h})$, (d) arachidonic acid $(\mathrm{AA})$ intake $(\mathrm{mg} / \mathrm{h})$, and $(\mathrm{e}) \mathrm{DHA}$ intake $(\mathrm{mg} / \mathrm{h})$ at 7 (early stage), 14 (middle stage) and 21 (late stage) days of lactation (dL). Rats were fed control (C: $-20 \%$ protein; $n 7$ per each stage) or restricted (R: $-10 \%$ protein; $n 6$ per each stage) diet during pregnancy and lactation. Values are means, with their standard errors represented by vertical bars. $P<0.05 \mathrm{v}$. $\mathrm{C}$. Data not sharing a letter are different between ages in the same group $(P<0.05)$. $\bullet, \mathrm{C}$ group; $\circ$, R group.

lactation and its association with pups' liver and brain weight and hippocampal AA and DHA content at weaning.

Carefully controlled studies in precocial and altricial mammalian species provide insights into the mechanisms involved. Humans are monotocous and precocial species, meaning that women generally bear only one fetus at a fairly advanced stage of metabolic development. In contrast, rodents are polytocous and altricial, bearing large litters born at an immature stage after relatively short pregnancies and requiring considerable maternal care in the immediate postnatal period to regulate basic neonatal functions. Thus, even under optimal feeding conditions, the nutritional demands of pregnancy and lactation on the litter-bearing rodent mother are much greater compared with humans. The present study analyses the effects of maternal LPD on mother, milk and offspring outcomes in a rat model, which is a limitation of the study. However, comparative physiology provides the opportunity to observe the differences and similarities between species by understanding the differences in molecular, cellular, biochemical and hormonal mechanisms. Understanding these differences can provide insights that can guide interventions in cases of abnormal human development ${ }^{(10)}$.

It has been reported that maternal food intake relative to the body weight, liver and MG weights is greater in lactating compared with non-lactating rats ${ }^{(26,32)}$. In line with our findings, an increment in liver weight during lactation is related to increased maternal lipogenesis and $\beta$-oxidation processes ${ }^{(18,35-38)}$. Normal MG proliferation as well as functional differentiation are complex phenomena controlled by many hormones and growth factors ${ }^{(39)}$. C mothers showed increased MG weight at mid lactation associated with increased milk production. In contrast, maternal LPD impairs MG differentiation, proliferation and development throughout lactation accompanied by negative effects on milk nutrient content, milk production and pup milk intake.

Numerous metabolic adaptations occur during pregnancy ${ }^{(4)}$ and lactation ${ }^{(40)}$ to support milk synthesis without jeopardising maternal substrate homeostasis while optimising the delivery of appropriate nutrition to the offspring ${ }^{(40,41)}$. We showed low desaturase and elongase gene expression at the end of gestation in LPD-fed mothers in both liver ${ }^{(22)}$ and $\mathrm{MG}^{(4)}$. These lower levels were further associated with a low percentage of LC-PUFA in maternal liver ${ }^{(22)}$ and $\mathrm{MG}^{(4)}$, as well as with poor fetal brain maturation, demonstrating negative impacts on both maternal and fetal homeostasis. Adequate maternal protein intake is necessary during both gestation and lactating periods ${ }^{(4)}$. Protein restriction during pregnancy does not affect maternal nursing behaviour, but the mobilisation of maternal stores may be insufficient for nutrient delivery to the pups ${ }^{(42)}$.

Pup milk intake was higher in $\mathrm{C}$ than $\mathrm{R}$ at all stages. Maternal LPD was found to decrease the suckling stimulus in newborns due to a low milk volume ${ }^{(19,43)}$. Milk yield also decreased because of protein reduction in the diet during gestation and lactation ${ }^{(44,45)}$. As a result, low neonate suckling behaviour negatively impacts total milk production, potentially due to a change in orexigenic drive in the pups' appetitive centre at the hypothalamic level ${ }^{(7)}$. Non-human primate fetuses whose mothers were undernourished showed increased orexigenic and decreased anorexigenic peptides in the arcuate nucleus appetitive centres ${ }^{(46)}$.

Milk protein concentration was higher at mid lactation in $\mathrm{C}$, the time of maximum milk production in rodents ${ }^{(7,47,48)}$. In contrast, in $\mathrm{R}$, protein concentration was lower than in $\mathrm{C}$ and did not show a peak during lactation. A reduction in maternal protein intake led to lower protein and amino acid availability to the pup, which together impaired pup's health and growth ${ }^{(49,50)}$. Contrasting 
(a)

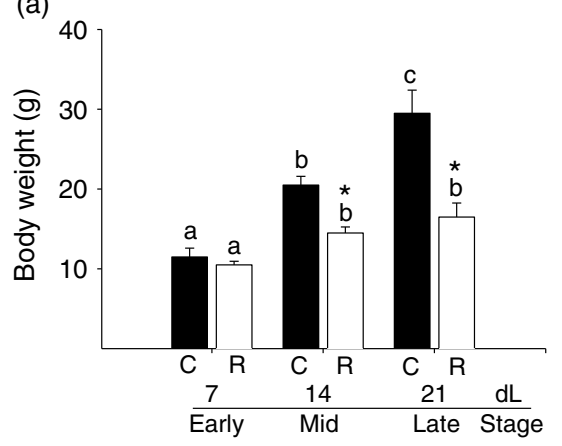

(b)

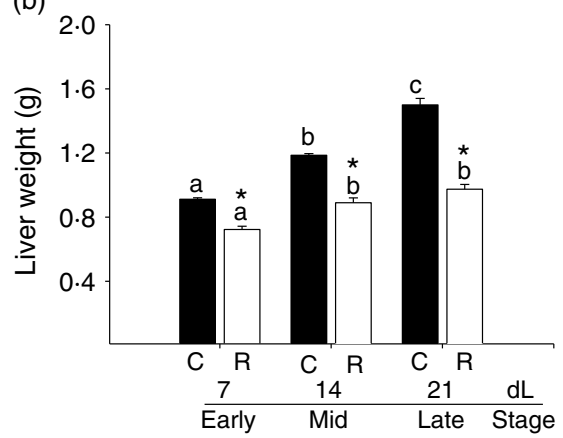

(c)

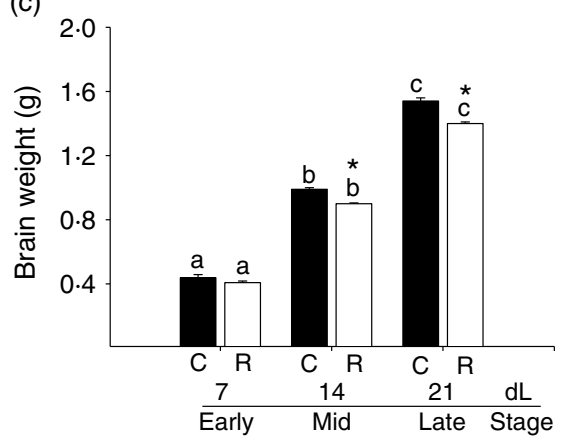

(d)

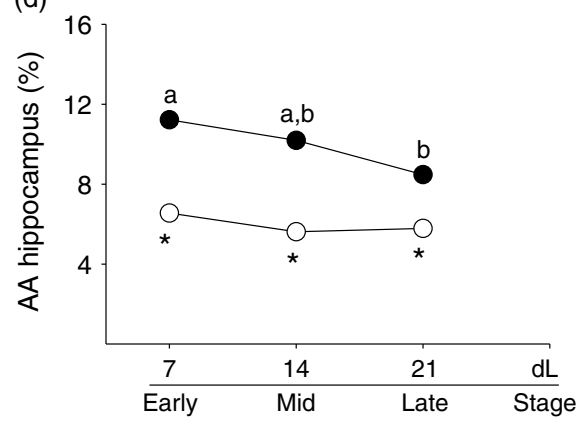

(e)

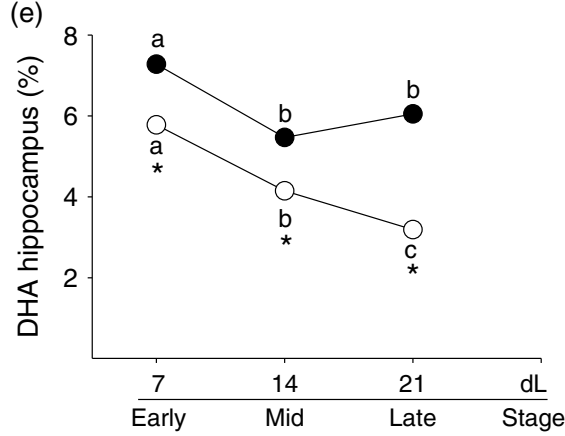

Fig. 6. Pup parameters. (a) Body weight (g), (b) liver weight (g), (c) brain weight (g), (d) arachidonic acid (AA) hippocampus (\%) and (e) DHA hippocampus (\%) at 7 (early stage), 14 (middle stage) and 21 (late stage) days of lactation (dL). Rats were fed control (C: $-20 \%$ protein; $n 7$ per each stage) or restricted (R: $-10 \%$ protein; $n 6$ per each stage) diet during pregnancy and lactation. Values are means, with their standard errors represented by vertical bars. ${ }^{*} P<0.05 v$. C. Data not sharing a letter are different between ages in the same group $(P<0.05)$. $\bullet$ C group; $\odot$, R group.

our results, Grigor et al. found no changes in protein and lipid concentrations in the milk of rats fed low-protein or energy-restricted diets at mid lactation ${ }^{(51)}$. In agreement with our results, other studies showed that protein restriction in the first half of the lactating phase reduced milk protein concentrations ${ }^{(52-55)}$. Total protein and casein concentrations gradually increased throughout lactation in rats that doubled their pup weight in $5 \mathrm{~d}$ out of a weaning period of $21 \mathrm{~d}$. Human babies doubled their weight in $120 \mathrm{~d}$ by consuming only their mother's milk ${ }^{(20)}$. Therefore, from the beginning of lactation, rats need to provide sufficient proteins to support the pups' organ development ${ }^{56,57)}$. Human milk contains $1.2 \mathrm{mg} / \mathrm{l}$ protein, while rat milk contains 10 times that amount (around $11.8 \mathrm{mg} / \mathrm{l})$, providing enough nutrients to double the infant's birth weight in $<5 \mathrm{~d}^{(50,56)}$. Under normal conditions, rats produce around $1.5 \mathrm{ml} / \mathrm{h}$ milk for $\geq 10$ pups $^{(14)}$, while women produce $50 \mathrm{ml} / \mathrm{h}$ milk for one or two infants ${ }^{(58,59)}$. Changes in the protein composition of human milk from colostrum to late lactation are associated with environmental variables such as feeding daytime ${ }^{(50)}$. Differences are also associated with maternal geographical location (temperature, elevation, etc.), cultural, and ethnic factors $^{(60,61)}$. In contrast, since rats were maintained under controlled experimental conditions, changes in the protein content of rat milk only depended on the lactation stage and were relatively independent of environmental changes ${ }^{(31)}$.

Our study did not modify the quantity or quality of fat in the maternal diet; only protein content was changed. Milk fat concentration was similar in both groups, in contrast to another study that reported a higher milk fat concentration at the beginning of lactation in rats fed a $\mathrm{LPD}^{(55)}$. However, pup fat intake reduced in $\mathrm{R}$ mothers at all stages of lactation. Maternal LPD reduced the percentage of milk DHA as well as milk DHA intake at late lactation.

Other studies have shown that maternal LPD negatively programmed pup's brain development ${ }^{(22,62)}$ and behaviour ${ }^{(63)}$ in ways that continued into adulthood. DHA supplementation in rat mothers fed with a LPD restored milk fatty acid composition and brain development ${ }^{(64)}$. Maternal DHA consumption increased milk and infant plasma DHA levels in both human ${ }^{(65)}$ and baboon studies ${ }^{(66,67)}$. Importantly, the biochemical form of long-chain polyunsaturates in milk affects incorporation into the neonatal brain ${ }^{(68)}$.

Early programming by maternal LPD affects body, liver and brain development. Lower percentages of hippocampal AA and DHA correlate with neural cell membrane composition and cognitive function in early life ${ }^{(67,69)}$. These results also are in line with our previous studies showing that maternal LPD programmed offspring liver and brain development, metabolic dysfunction $^{(70,71)}$, adult life appetitive behaviour, lower body weight and leptin serum concentrations ${ }^{(70,71)}$. LPD was found to impair reproductive functions ${ }^{(72,73)}$, delaying sexual maturation, onset of puberty and decreased sperm quality ${ }^{(74)}$. LPD also causes offspring anxiety-type behaviour and learning and cognitive problems ${ }^{(9,63,75)}$. Here we found that offsprings of LPD-fed rats had lower hippocampal AA and DHA (\%). The brain is the most complex and interactive organ in the body. The hippocampal region is closely involved in the control of both short- and long-term memory and in memories associated with spatial learning and planning $^{(67,69,76,77)}$. 
To our knowledge few studies have been conducted to identify the effects of inadequate maternal protein diet on maternal MG function and offspring nutrient delivery during lactation; studies that have been reported addressed mostly milk composition $^{(44)}$. This is unfortunate since a LPD has been extensively studied to induce developmental programming in the offspring ${ }^{(54,78)}$. The present study provides data on the effects of LPD on maternal outcomes in key organs, milk production and composition, and pups' organ development in a rat model. Milk also confers bioactive molecules that are known to protect the mother and offspring from infections and inflammation, contributing to maternal and neonatal immune maturation, organ development and healthy microbial colonisation $^{(50)}$.

In conclusion, maternal LPD delayed MG differentiation and milk production, affecting the pups' milk nutrient intake, with negative consequences on the development of multiple organs in pups by weaning. Adequate maternal nutrition during lactation is a key factor in offspring's life course health.

\section{Acknowledgements}

C. I. is a graduate student from Doctorado en Ciencias Bioquímicas, Universidad Nacional Autónoma de México, and is recipient of a Consejo Nacional de Ciencia y Tecnología (CONACyT) fellowship (262656).

This work was supported by CONACyT (E. Z., 155166), Mexico City, Mexico.

CONACyT had no role in the design, analysis or writing of this article.

C. J. B.: researched data, study design, manuscript writing; R. J. B., S. M. and L. R. C.: researched data; O. N. R. and C. A. I.: contributed to discussion and reviewed manuscript; P. W. N.: study design and preparation of the manuscript; E. Z.: responsible for the study design and preparation of the manuscript.

There were no conflicts of interest.

\section{References}

1. Liu Z, Roy NC, Guo Y, et al. (2016) Human breast milk and infant formulas differentially modify the intestinal microbiota in human infants and host physiology in rats. J Nutr 146, 191-199.

2. Wright CJ, Atkinson FS, Ramalingam N, et al. (2015) Effects of human milk and formula on postprandial glycaemia and insulinaemia. Eur J Clin Nutr 69, 939-943.

3. Walker A (2010) Breast milk as the gold standard for protective nutrients. J Pediatr 156, S3-S7.

4. Bautista CJ, Rodriguez-Gonzalez GL, Torres N, et al. (2013) Protein restriction in the rat negatively impacts long-chain polyunsaturated fatty acid composition and mammary gland development at the end of gestation. Arch Med Res 44, 429-436.

5. Gessner DK, Grone B, Rosenbaum S, et al. (2015) Effect of a negative energy balance induced by feed restriction in lactating sows on hepatic lipid metabolism, milk production and development of litters. Arch Anim Nutr 69, 399-410.

6. Park CS (2005) Role of compensatory mammary growth in epigenetic control of gene expression. FASEB J 19, 1586-1591.

7. Bautista CJ, Boeck L, Larrea F, et al. (2008) Effects of a maternal low protein isocaloric diet on milk leptin and progeny serum leptin concentration and appetitive behavior in the first 21 days of neonatal life in the rat. Pediatr Res 63, 358-363.

8. Hanson MA \& Gluckman PD (2015) Developmental origins of health and disease-global public health implications. Best Pract Res Clin Obstet Gynaecol 29, 24-31.

9. Reyes-Castro LA, Padilla-Gomez E, Parga-Martinez NJ, et al. (2018) Hippocampal mechanisms in impaired spatial learning and memory in male offspring of rats fed a low-protein isocaloric diet in pregnancy and/or lactation. Hippocampus 28, 18-30.

10. Zambrano E \& Nathanielsz PW (2013) Mechanisms by which maternal obesity programs offspring for obesity: evidence from animal studies. Nutr Rev 71, S42-S54.

11. Vieau D (2011) Perinatal nutritional programming of health and metabolic adult disease. World J Diabetes 2, 133-136.

12. Levant B, Ozias MK \& Carlson SE (2006) Diet ( $n$-3) polyunsaturated fatty acid content and parity interact to alter maternal rat brain phospholipid fatty acid composition. J Nutr 136, 2236-2242.

13. Cao D, Kevala K, Kim J, et al. (2009) Docosahexaenoic acid promotes hippocampal neuronal development and synaptic function. J Neurochem 111, 510-521.

14. Bautista CJ, Montano S, Ramirez V, et al. (2016) Changes in milk composition in obese rats consuming a high-fat diet. BrJ Nutr 115, 538-546.

15. Nakamura MT \& Nara TY (2004) Structure, function, and dietary regulation of delta6, delta5, and delta9 desaturases. Annu Rev Nutr 24, 345-376.

16. Rodriguez-Cruz M, Tovar AR, Palacios-Gonzalez B, et al. (2006) Synthesis of long-chain polyunsaturated fatty acids in lactating mammary gland: role of Delta5 and Delta6 desaturases, SREBP-1, PPARalpha, and PGC-1. J Lipid Res 47, $553-560$

17. Bautista CJ \& Zambrano E (2010) Biology and biochemical aspects of long-chains polyunsaturated fatty acid during gestation. Rev Invest Clin 62, 267-275.

18. Ramos-Lobo AM, Furigo IC, Teixeira PDS, et al. (2018) Maternal metabolic adaptations are necessary for normal offspring growth and brain development. Physiol Rep 6, e13643.

19. Cherala G, Shapiro BH \& D'Mello AP (2006) Two low protein diets differentially affect food consumption and reproductive performance in pregnant and lactating rats and long-term growth in their offspring. J Nutr 136, 2827-2833.

20. Nicholas KR \& Hartmann PE (1991) Milk secretion in the rat: progressive changes in milk composition during lactation and weaning and the effect of diet. Comp Biochem Physiol A Comp Physiol 98, 535-542.

21. Liu D, Diorio J, Tannenbaum B, et al. (1997) Maternal care, hippocampal glucocorticoid receptors, and hypothalamicpituitary-adrenal responses to stress. Science 277, 1659-1662.

22. Torres N, Bautista CJ, Tovar AR, et al. (2010) Protein restriction during pregnancy affects maternal liver lipid metabolism and fetal brain lipid composition in the rat. Am $J$ Physiol Endocrinol Metab 298, E270-E277.

23. Moretto VL, Ballen MO, Goncalves TS, et al. (2011) Low-protein diet during lactation and maternal metabolism in rats. ISRN Obstet Gynecol 2011, 876502.

24. Wattez JS, Delmont A, Bouvet M, et al. (2015) Maternal perinatal undernutrition modifies lactose and serotranferrin in milk: relevance to the programming of metabolic diseases? $\mathrm{Am} \mathrm{J}$ Physiol Endocrinol Metab 308, E393-E401.

25. Fiorotto ML, Burrin DG, Perez M, et al. (1991) Intake and use of milk nutrients by rat pups suckled in small, medium, or large litters. Am J Physiol 260, R1104-R1113.

26. Cambraia RP, Vannucchi H \& De-Oliveira LM (1997) Food intake and weight of lactating rats maintained on different 
protein-calorie diets, and pup growth. Braz J Med Biol Res 30 , 985-988.

27. Vega CC, Reyes-Castro LA, Rodriguez-Gonzalez GL, et al. (2016) Resveratrol partially prevents oxidative stress and metabolic dysfunction in pregnant rats fed a low protein diet and their offspring. J Physiol 594, 1483-1499.

28. Herlich K (editor) (1990) Official Methods of Analysis of the Association of Official Analytical Chemists. Arlington, VA: The Association of Official Analytical Chemists.

29. Russell JA (1980) Milk yield, suckling behaviour and milk ejection in the lactating rat nursing litters of different sizes.J Physiol 303, 403-415.

30. Romero JJ, Canas R \& Baldwin RL (1975) A technique for estimating milk production in rats. J Nutr 105, 413-420.

31. Martin CR, Ling PR \& Blackburn GL (2016) Review of infant feeding: key features of breast milk and infant formula. Nutrients $\mathbf{8}, 279$.

32. Keen CL, Lonnerdal B, Clegg M, et al. (1981) Developmental changes in composition of rat milk: trace elements, minerals, protein, carbohydrate and fat. J Nutr 111, 226-236.

33. Sturman JADE, Resnick O \& Morgane PJ (1986) Maternal protein malnutrition in the rat: effect on protein and two enzymes in the milk. Nutr Res 6, 437-442.

34. Jahan-Mihan A, Rodriguez J, Christie C, et al. (2015) The role of maternal dietary proteins in development of metabolic syndrome in offspring. Nutrients 7, 9185-9217.

35. Bertics SJ, Grummer RR, Cadorniga-Valino C, et al. (1992) Effect of prepartum dry matter intake on liver triglyceride concentration and early lactation. J Dairy Sci 75, 1914-1922.

36. Kuhla B, Kucia M, Gors S, et al. (2010) Effect of a highprotein diet on food intake and liver metabolism during pregnancy, lactation and after weaning in mice. Proteomics 10, 2573-2588.

37. Vernon RG, Denis RG, Sorensen A, et al. (2002) Leptin and the adaptations of lactation in rodents and ruminants. Horm Metab Res 34, 678-685.

38. Zambrano E, Ibanez C, Martinez-Samayoa PM, et al. (2016) Maternal obesity: lifelong metabolic outcomes for offspring from poor developmental trajectories during the perinatal period. Arch Med Res 47, 1-12.

39. Bhattacharjee M, Wientroub S \& Vonderhaar BK (1987) Milk protein synthesis by mammary glands of vitamin D-deficient mice. Endocrinology 121, 865-874.

40. Mohammad MA, Sunehag AL \& Haymond MW (2009) Effect of dietary macronutrient composition under moderate hypocaloric intake on maternal adaptation during lactation. Am J Clin Nutr 89, 1821-1827.

41. Bauman DE \& Currie WB (1980) Partitioning of nutrients during pregnancy and lactation: a review of mechanisms involving homeostasis and homeorhesis. J Dairy Sci 63, 1514-1529.

42. Koiter TR, Moes H \& Valkhof N, et al. (1999) Interaction of late pregnancy and lactation in rats. J Reprod Fertil 115, 341-347.

43. Swierczynski J \& Sledzinski T (2012) Metabolic and regulatory function of fatty acid synthase. Postepy Biochem 58, 175-185.

44. Martin Agnoux A, Antignac JP, Boquien CY, et al. (2015) Perinatal protein restriction affects milk free amino acid and fatty acid profile in lactating rats: potential role on pup growth and metabolic status. J Nutr Biochem 26, 784-795.

45. Sampson DA \& Jansen GR (1984) Measurement of milk yield in the lactating rat from pup weight and weight gain. $J$ Pediatr Gastroenterol Nutr 3, 613-617.

46. Li C, McDonald TJ, Wu G, et al. (2013) Intrauterine growth restriction alters term fetal baboon hypothalamic appetitive peptide balance. J Endocrinol 217, 275-282.
47. Bonomo IT, Lisboa PC, Passos MC, et al. (2005) Prolactin inhibition in lactating rats changes leptin transfer through the milk. Horm Metab Res 37, 220-225.

48. Rayner DV, Dalgliesh GD, Duncan JS, et al. (1997) Postnatal development of the ob gene system: elevated leptin levels in suckling fa/fa rats. Am J Physiol 273, R446-R450.

49. Wada Y, Phinney BS, Weber D, et al. (2016) In vivo digestomics of milk proteins in human milk and infant formula using a suckling rat pup model. Peptides 88, 18-31.

50. Ballard O \& Morrow AL (2013) Human milk composition: nutrients and bioactive factors. Pediatr Clin North America 60, 49-74.

51. Grigor MR, Allan JE, Carrington JM, et al. (1987) Effect of dietary protein and food restriction on milk production and composition, maternal tissues and enzymes in lactating rats. J Nutr 117, $1247-1258$.

52. Ramos CF, Teixeira CV, Passos MC, et al. (2000) Low-protein diet changes thyroid function in lactating rats. Proc Soc Exp Biol Med 224, 256-263.

53. Passos MC, Ramos CF, Bernardo-Filho M, et al. (2000) The effect of protein or energy restriction on the biodistribution of Na99TcmO4 in Wistar rats. Nucl Med Commun 21, 1059-1062.

54. Pine AP, Jessop NS \& Oldham JD (1994) Maternal protein reserves and their influence on lactational performance in rats. Br J Nutr 71, 13-27.

55. Palmquist DL, Beaulieu AD \& Barbano DM (1993) Feed and animal factors influencing milk fat composition. J Dairy Sci 76, 1753-1771.

56. Veith WJ (2012) Want more protein from milk? Rat's milk is your answer. In wordpresscom, vol. 2012 [JM Hicks, editor]. https:// hpjmh.com/2012/02/21/want-more-protein-from-milk-rats-milkis-your-answer/: unleashing the power of plant-based nutrition

57. Cox DB, Kent JC, Casey TM, et al. (1999) Breast growth and the urinary excretion of lactose during human pregnancy and early lactation: endocrine relationships. Exp Physiol 84, 421-434.

58. Kent JC, Mitoulas LR, Cregan MD, et al. (2006) Volume and frequency of breastfeedings and fat content of breast milk throughout the day. Pediatrics 117, e387-e395.

59. Kent JC, Hepworth AR, Sherriff JL, et al. (2013) Longitudinal changes in breastfeeding patterns from 1 to 6 months of lactation. Breastfeeding Med 8, 401-407.

60. Su LL, Thamarai Chelvi SK, Lim SL, et al. (2010) The influence of maternal ethnic group and diet on breast milk fatty acid composition. Ann Acad Med Singapore 39, 675-675.

61. Pak-Gorstein S, Haq A \& Graham EA (2009) Cultural influences on infant feeding practices. Pediatr Rev 30, e11-e21.

62. Brenna JT (2013) Commentary on 'Maternal long-chain PUFA supplementation during protein deficiency improves brain fatty acid accretion in rat pups by altering the milk fatty acid composition of the dam' by Ranade and Rao. J Nutr Sci $\mathbf{2}$, e4.

63. Reyes-Castro LA, Rodriguez JS, Charco R, et al. (2012) Maternal protein restriction in the rat during pregnancy and/or lactation alters cognitive and anxiety behaviors of female offspring. Int J Dev Neurosci 30, 39-45.

64. Brenna JT, Salem N, Jr., Sinclair AJ, et al. (2009) Alpha-Linolenic acid supplementation and conversion to n-3 long-chain polyunsaturated fatty acids in humans. Prostaglandins Leukot Essent Fatty Acids 80, 85-91.

65. Sherry CL, Oliver JS \& Marriage BJ (2015) Docosahexaenoic acid supplementation in lactating women increases breast milk and plasma docosahexaenoic acid concentrations and alters infant omega 6:3 fatty acid ratio. Prostaglandins Leukot Essent Fatty Acids 95, 63-69. 
66. Carlson SE \& Colombo J (2016) Docosahexaenoic acid and arachidonic acid nutrition in early development. Adv Pediatr 63, 453-471.

67. Diau GY, Hsieh AT, Sarkadi-Nagy EA, et al. (2005) The influence of long chain polyunsaturate supplementation on docosahexaenoic acid and arachidonic acid in baboon neonate central nervous system. BMC Med 3, 11.

68. Wijendran V, Huang MC, Diau GY, et al. (2002) Efficacy of dietary arachidonic acid provided as triglyceride or phospholipid as substrates for brain arachidonic acid accretion in baboon neonates. Pediatr Res 51, 265-272.

69. Heird WC \& Lapillonne A (2005) The role of essential fatty acids in development. Annu Rev Nutr 25, 549-571.

70. Zambrano E, Martinez-Samayoa PM, Bautista CJ, et al. (2005) Sex differences in transgenerational alterations of growth and metabolism in progeny (F2) of female offspring (F1) of rats fed a low protein diet during pregnancy and lactation. $J$ Physiol 566, 225-236.

71. Zambrano E, Bautista CJ, Deas M, et al. (2006) A low maternal protein diet during pregnancy and lactation has sex- and window of exposure-specific effects on offspring growth and food intake, glucose metabolism and serum leptin in the rat.JPhysiol 571, 221-230.

72. Rodriguez-Gonzalez GL, Vigueras-Villasenor RM, Millan S, et al. (2012) Maternal protein restriction in pregnancy and/or lactation affects seminiferous tubule organization in male rat offspring. J Dev Orig Health Dis 3, 321-326.

73. Rodriguez-Gonzalez GL, Vega CC, Boeck L, et al. (2015) Maternal obesity and overnutrition increase oxidative stress in male rat offspring reproductive system and decrease fertility. Int J Obes (Lond) 39, 549-556.

74. Rodriguez-Gonzalez GL, Reyes-Castro LA, Vega CC, et al. (2014) Accelerated aging of reproductive capacity in male rat offspring of protein-restricted mothers is associated with increased testicular and sperm oxidative stress. Age (Dordr) 36, 9721.

75. Reyes-Castro LA, Rodriguez JS, Rodriguez-Gonzalez GL, et al. (2011) Pre- and/or postnatal protein restriction in rats impairs learning and motivation in male offspring. Int J Dev Neurosci 29, 177-182.

76. Buzsaki G (2015) Hippocampal sharp wave-ripple: a cognitive biomarker for episodic memory and planning. Hippocampus 25, 1073-1188.

77. Castro-Chavira SA, Aguilar-Vazquez AR, Martinez-Chavez Y, et al. (2016) Effects of chronic malnourishment and aging on the ultrastructure of pyramidal cells of the dorsal hippocampus. Nutr Neurosci 19, 329-336.

78. Agnoux AM, El Ghaziri A, Moyon T, et al. (2018) Maternal protein restriction during lactation induces early and lasting plasma metabolomic and hepatic lipidomic signatures of the offspring in a rodent programming model. J Nutr Biochem 55, 124-141. 